\title{
Ablation of TGFBR3 (betaglycan) in oocytes does not affect fertility in female mice
}

\author{
Yining Li ${ }^{1}$, Yeu-Farn Lin ${ }^{1}$, Xiang Zhou ${ }^{1}$, Hugh J Clarke² and Daniel J Bernard ${ }^{1}$ \\ ${ }^{1}$ Department of Pharmacology and Therapeutics, McGill University, Montréal, Québec, Canada and ${ }^{2}$ Department \\ of Obstetrics and Gynecology, McGill University, Montréal, Québec, Canada
}

Correspondence should be addressed to D J Bernard; Email: daniel.bernard@mcgill.ca

\begin{abstract}
Ovarian follicle development is regulated by locally produced TGF $\beta$ superfamily members. The TGF $\beta$ type III receptor (TGFBR3, or betaglycan), which regulates the actions of diverse TGF $\beta$ ligands, including inhibins, is expressed in different ovarian cell types. However, its functional roles in the ovary have not been investigated in vivo. Here, we ablated Tgfbr3 in murine oocytes using the Cre-loxP system. Oocyte-specific Tgfbr3 knockout (cKO) females were fertile, producing litters of similar size and frequency as controls. Their ovarian weights and histology were also normal. Though we confirmed efficient recombination of the floxed alleles, we did not detect Tgfbr3 mRNA in purified oocytes from superovulated cKO or control mice. These results challenge earlier observations of betaglycan protein expression in this cell type. Regardless, Tgfbr3 in the murine oocyte is clearly dispensable for female fertility.

Reproduction (2021) 161 289-294
\end{abstract}

\section{Introduction}

Mammalian ovarian folliculogenesis is dependent on multiple endocrine and intra-ovarian ligands and their downstream signaling pathways. Whereas the pituitary hormones, luteinizing hormone (LH) and folliclestimulating hormone $(\mathrm{FSH})$, play well-known roles in follicle development and hormone production, proper growth and differentiation also require bidirectional paracrine signaling between germ and somatic cells (Matzuk et al. 2002, Gilchrist et al. 2004, Kidder \& Vanderhyden 2010). Indeed, disruption of the cross-talk between the oocyte and surrounding granulosa cells leads to failed folliculogenesis and infertility (Matzuk et al. 2002, Gilchrist et al. 2004, Kidder \& Vanderhyden 2010).

Communication between the oocyte and somatic cells is highly dependent on ligands in the transforming growth factor beta (TGF $\beta$ ) superfamily, including growth differentiation factor 9 (GDF9) (Massague 1998, Juengel \& McNatty 2005, Myers \& Pangas 2010, Knight et al. 2012). TGF $\beta$ ligands signal through complexes of type I and II serine-threonine kinase receptors that activate the homolog of Drosophila mothers against decapentaplegic (SMAD) family of signaling proteins to regulate gene expression (Massague 1998, Attisano \& Wrana 2002). In addition, some TGF $\beta$ superfamily ligands, such as the TGF $\beta$ s and inhibins, rely on so-called type III receptors to mediate their actions (Massague 1998).

The TGF $\beta$ type III receptor (TGFBR3, also known as betaglycan), which lacks kinase activity, binds the TGF $\beta$ s and facilitates their interaction with the type II receptor, TGFBR2 (Bilandzic \& Stenvers 2011). In addition to binding TGF $\beta$ s, TGFBR3 also functions as an inhibin co-receptor (Lewis et al. 2000, Chapman et al. 2002, Wiater et al. 2009, Li et al. 2018). Inhibins A and B are heterodimers of the inhibin $\alpha$ subunit disulfide-linked to either the inhibin $\beta A$ (inhibin $A$ ) or $\beta B$ (inhibin B) subunits. Homo- and heterodimers of the inhibin $\beta$ subunits form the activins (Ling et al. 1986a, Ling et al. 1986b). According to in vitro models, inhibins $A$ and $B$ antagonize the actions of activins by forming ternary complexes with activin type II receptors and TGFBR3. This sequesters the type II receptors, inhibiting activin binding and signaling (Lewis et al. 2000, Chapman et al. 2002). Inhibins can similarly inhibit BMP signaling by sequestering the relevant type II receptors (ACVR2A, ACVR2B, and the BMP type II receptor, BMPR2) in the presence of TGFBR3 (Wiater \& Vale 2003, Vale et al. 2004, Farnworth et al. 2006). TGFBR3 can also potentiate the actions of some BMPs (Bilandzic \& Stenvers 2011). Thus, TGFBR3 promotes or inhibits the signaling of several TGF $\beta$ superfamily ligands in a context-specific manner.

TGFBR3 protein and Tgfbr3 mRNA have been detected in murine oocytes, granulosa cells, and theca cells, but the protein's roles therein have not yet been determined in vivo (Lewis et al. 2000, Drummond et al. 2002, MacConell et al. 2002). In theca cell cultures, inhibin A upregulates androgen production and antagonizes BMP4, 6, 7, and activin A signalling, perhaps via TGFBR3 (Hillier et al. 1991, Glister et al. 
2010). Complexes of inhibin A bound to TGFBR3 and ACVR2A can be immunoprecipitated from KK-1 cells (a murine granulosa cell line), suggesting that TGFBR3 may mediate inhibin actions in granulosa cells (Lewis et al. 2000). In cows, inhibin A inhibits oocyte maturation and developmental competence (O et al. 1989, Silva et al. 1999). Activin A, in contrast, has the opposite effects in both cows and rodents (Sadatsuki et al. 1993, Silva \& Knight 1998). Whether inhibins act via TGFBR3 in oocytes or somatic cells to produce these effects is unclear. Here, we generated oocyte-specific Tgfbr3 knockout mice to investigate potential roles of the TGFBR3 protein in germ cell function and female fertility.

\section{Materials and methods}

\section{Generation of conditional knockout mice}

Tgfbr $3^{\text {fx/fx }}$ mice (on a mixed C57BL6 and 129SvEv background) were previously described ( $\mathrm{Li}$ et al. 2018). Tgfbr $3^{\mathrm{fx} / \mathrm{fx}}$ females were crossed with Gdf9-iCre males (011062; The Jackson Laboratory) to generate $\mathrm{Tgfbr} 3^{\mathrm{f} x /+} ; \mathrm{Gdf9}-\mathrm{iCre} /+$ progeny (Lan et al. 2004). Tgfbr $3^{\mathrm{fx} /+} ; G d f 9-\mathrm{iCre} /+$ males were then crossed with Tgfbr $3^{\mathrm{fx} / \mathrm{fx}}$ females to obtain Tgfbr $3^{\mathrm{fx} / \mathrm{fx}} ; G d f 9-\mathrm{iCre} /+$ offspring. Finally, Tgfbr $3^{\text {fx/fx}} ; G d f 9-i C r e /+$ males were crossed with Tgfbr $3^{\mathrm{fx} / \mathrm{fx}}$ females to generate $T g f b r 3^{\mathrm{fx} / \mathrm{fx}}$ (control) and conditional knockout Tgfbr $3^{\mathrm{fx} / \mathrm{fx}} ; \mathrm{Gdf9}$-iCre/+ (cKO) littermates. As Gdf9-iCre is expressed in female (but not male) germ cells, this allele was contributed by the male in our crosses. PCR primers used for genotyping and to assess genomic recombination are listed in Table 1 . Animals were housed on a $12 \mathrm{~h}$ light:12 h darkness cycle and were given access to food and water ad libitum. All animal work was performed in accordance with institutional and federal guidelines and approved by the McGill University and Goodman Cancer Centre Facility Animal Care Committee (protocol 5204).

Table 1 Genotyping and qPCR primers.

\begin{tabular}{|c|c|}
\hline \multicolumn{2}{|l|}{ Genotyping } \\
\hline \multicolumn{2}{|l|}{ Tgfbr3 } \\
\hline Forward & TGATCTTAGTGGTAACCTCGCC \\
\hline Reverse & CTAGCATGACAGGAATGTAC \\
\hline Recombined & TTAGGTCGGTGCTGTCCTTGTT \\
\hline \multicolumn{2}{|l|}{ Gdf9-iCre } \\
\hline Forward & TCTGATGAAGTCAGGAAGAACC \\
\hline Reverse & GAGATGTCCTTCACTCTGATTC \\
\hline \multicolumn{2}{|l|}{ qPCR } \\
\hline \multicolumn{2}{|l|}{ Rp/19 } \\
\hline Forward & CGGGAATCCAAGAAGATTGA \\
\hline Reverse & TTCAGCTTGTGGATGTGCTC \\
\hline \multicolumn{2}{|l|}{ Tgfbr3 } \\
\hline Forward & TGTTGGAGAGATGGCAGTGA \\
\hline Reverse & TGGACTGGATGAGAGGCACT \\
\hline \multicolumn{2}{|l|}{ Foxl2 } \\
\hline Forward & ACAACACCGGAGAAACCAGAC \\
\hline Reverse & CGTAGAACGGGAACTTGGCTA \\
\hline \multicolumn{2}{|l|}{ Gdf9 } \\
\hline Forward & TCTTAGTAGCСTTAGCTCTCAGG \\
\hline Reverse & TGTCAGTCCCATCTACAGGCA \\
\hline
\end{tabular}

Reproduction (2021) 161 289-294

\section{Assessment of puberty onset, estrous cyclicity, and fertility in females}

Puberty onset was assessed by monitoring vaginal opening daily following weaning at postnatal day 21 . From 7 weeks of age, females were swabbed daily at 10:00 h to assess estrous cyclicity, for a total of 3 weeks. Vaginal cytology was analyzed using $0.1 \%$ methylene blue, as previously described (Caligioni 2009).

To assess fertility, 10-week-old female control and cKO mice were paired with WT C57BL/6 males (000664, Charles River Senneville, Quebec, Canada) for a period of 6 months. Starting from 20 days after pairing, the cages were inspected daily for the presence of newborn mice. As soon as a litter was present, pups were carefully counted and put back into the cage. Pups were separated from the mother at postnatal day 15 .

\section{Reproductive organ analyses and ovarian histology}

Ovaries were collected from 10-week-old females on the afternoon of metestrus/diestrus and weighed on a precision balance. Ovarian histology was performed as previously described (Li et al. 2018) at the McGill Centre for Bone and Periodontal Research. Images were acquired with a Leica DFC310 FX 1.4-megapixel digital color camera with a Leica DM1000 LED light microscope using Leica Application Suite Version 4.0.0 software or with a Zeiss Axio Imager M2 microscope.

\section{Oocyte and cumulus cell purification}

Superovulation was performed in adult females as described previously (Li et al. 2017). Briefly, control and cKO females were i.p. injected with $5 \mathrm{IU}$ of pregnant mare's serum gonadotropin (eCG; G4877; Sigma). Forty-eight hours later, they were injected intraperitoneally with 5 IU of human chorionic gonadotropin (hCG; C1063; Sigma). Sixteen hours following the second injection, mice were euthanized and cumulus-oocyte complexes (COCs) were harvested in M199 culture medium (31100-035, Invitrogen) supplement with 10\% FBS (098150, Wisent, St-Bruno, Quebec, Canada). COCs were incubated in $10 \mu \mathrm{L} / \mathrm{mL}$ hyaluronidase (H3884, Millipore Sigma) for $10 \mathrm{~min}$ at $37^{\circ} \mathrm{C}$. Oocytes were then manually purified by mouth pipet. RNA was extracted from oocytes and cumulus cells using TRIzol reagent following the manufacturer's guidelines (15596018, ThermoFisher Scientific).

\section{RT-qPCR}

RNA concentration was determined by NanoDrop. cDNA was synthesized as previously described (Li et al. 2018). In brief, 1 $\mu \mathrm{g}$ of RNA per sample were reverse transcribed using Moloney murine leukemia virus reverse transcriptase (172807, Promega) and random hexamer primers (184865, Promega) in a final volume of $40 \mu \mathrm{L}$. Two microliters of cDNA were used for qPCR analysis on a Corbett Rotorgene 600 instrument (Corbett Life Science) using EvaGreen reagent (ABMMmix-S-XL, Diamed, Mississauga, Ontario, Canada) and primers listed in Table 1. Relative gene expression was normalized to the housekeeping gene, ribosomal protein L19 (Rp/19). All oligos were synthesized 


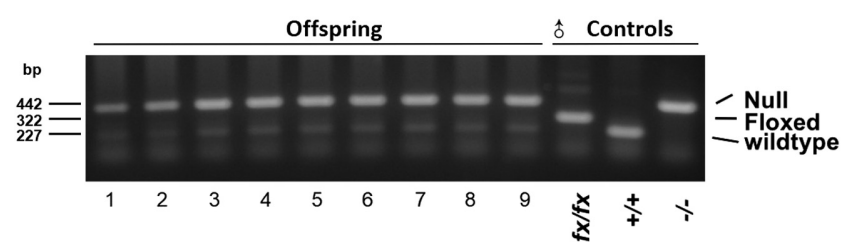

Figure 1 Recombination of the floxed Tgfbr3 allele in cKO mice. Tgfbr3fx/fx; Gdf9-iCre/+ (cKO) females were mated with WT (+/+) males. Genomic DNA was extracted from the tails of the offspring (lanes 1-9). PCR was performed to detect the presence of the WT, floxed, and null (recombined) Tgfbr3 alleles. Genomic DNA extracted from a Tgfbr3 global knockout embryo was used as the null allele control.

by Integrated DNA Technologies (IDT, Coralville, IA). All primer sets were validated for efficiency and specificity.

\section{Statistical analysis}

All data were analyzed on GraphPad Prism 8 using either Student $t$-tests or two-way ANOVA. Results were considered statistically significant if $P<0.05$.

\section{Results}

\section{Generation of oocyte-specific cKO mice}

To generate oocyte-specific Tgfbr3 knockout mice, we crossed floxed Tgfbr3 females to Tgfbr $3^{\text {fx/fx; }}$ Gdf9-iCre males. To assess recombination in oocytes, we mated conditional knockout (cKO; Tgfbr $3^{\text {fx/fx; }}$ Gdf9-iCre/+) females with WT males. PCR analysis of genomic DNA from the offspring showed one WT Tgfbr3 allele (from the father) and one null allele in all offspring, indicating that the floxed Tgfbr 3 allele had been efficiently recombined in oocytes (Fig. 1).

\section{cKO females have normal fertility}

Female cKO mice entered puberty (defined by day of vaginal opening) at the same age as control mice (Fig. 2A). Moreover, there were no differences in the amount of time control and $\mathrm{CKO}$ mice spent in each stage of the estrous cycle (Fig. 2B).

To assess fertility, we paired control and cKO female littermates with WT C57BL/6 males for 6 months. There were no differences in the number of pups per litter or in the frequency of litters between control and cKO females (Fig. 2C and D).

\section{cKO females have apparently normal gonadal development}

Next, we assessed whether loss of Tgfbr3 in oocytes affected gonadal development. There was no difference in ovarian weights between adult control and cKO mice
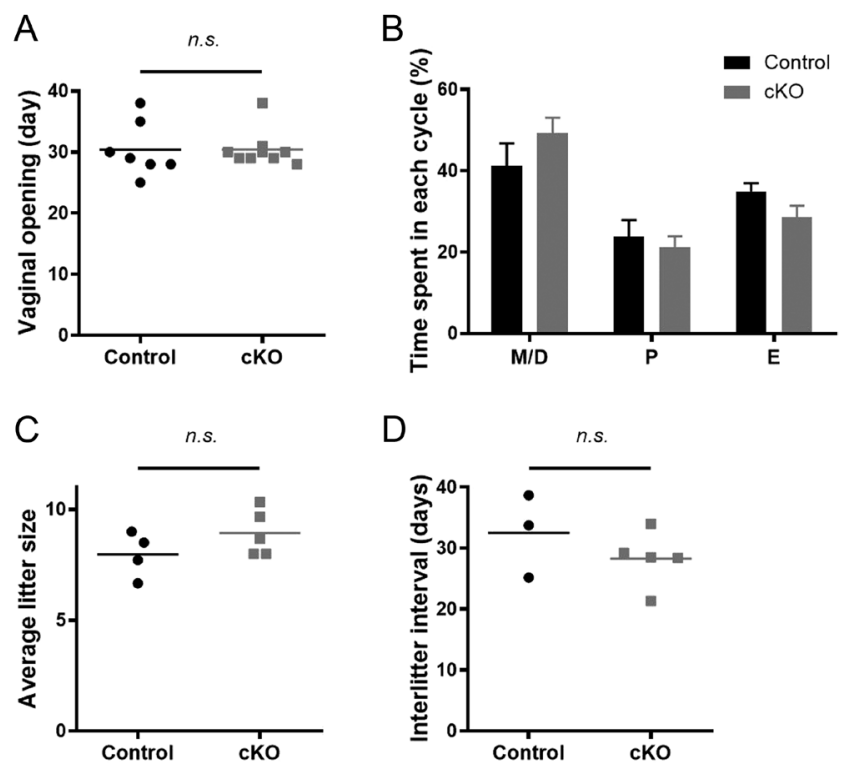

Figure 2 Normal fertility in cKO mice. (A) Puberty onset as assessed by day of vaginal opening in control $(n=7)$ and cKO $(n=9)$ females. (B) Percent of days in each stage of the estrous cycle in control $(n=6)$ and cKO $(n=9)$ females. Estrous cyclicity was assessed by vaginal cytology. Stages are indicated as estrus (E), proestrus (P), and metestrus/diestrus (M/D). (C and D) Female control and cKO littermates were paired with WT C57BL/6 males for 6 months. (C) Average number of pups per litter in control $(n=4)$ and cKO $(n=5)$ females. (D) Average number of days between litters. $t$-tests were used for statistical analyses of puberty onset, litter size, and litter frequency. Two-way ANOVA was used for statistical analysis of the estrous cycle. NS, not significantly different $(P>0.05)$.

(Fig. 3A). Additionally, ovarian histology was similar between genotypes, with follicles at all developmental stages observed (Fig. 3B). Although there were no obvious differences in follicle development between control and cKO mice, we did not systematically count the number of follicles.

\section{Tgfbr3 is expressed at low levels in the oocyte}

Though the floxed Tgfbr3 allele was efficiently recombined in oocytes (Fig. 1), we next examined the effects of the deletion on gene expression. We collected cumulus-oocyte complexes (COCs) from superovulated adult control and cKO females. The oocyte and granulosa cells were manually dissociated and purified. Gdf9 (Fig. 4A) and Fox/2 (Fig. 4B) mRNAs were exclusively detected in oocytes and cumulus cells, respectively, demonstrating the purity of the cell preparations. There were no differences in the expression of either gene between genotypes. Similarly, Tgfbr3 mRNA levels were not altered in cumulus cells of cKO mice relative to controls (Fig. 4C). Unexpectedly, Tgfbr3 mRNA expression was very low in oocytes of both genotypes. Indeed, in the control animals, Tgfbr3 expression in the oocyte was $0.09 \%$ of the level observed in cumulus cells. 
A
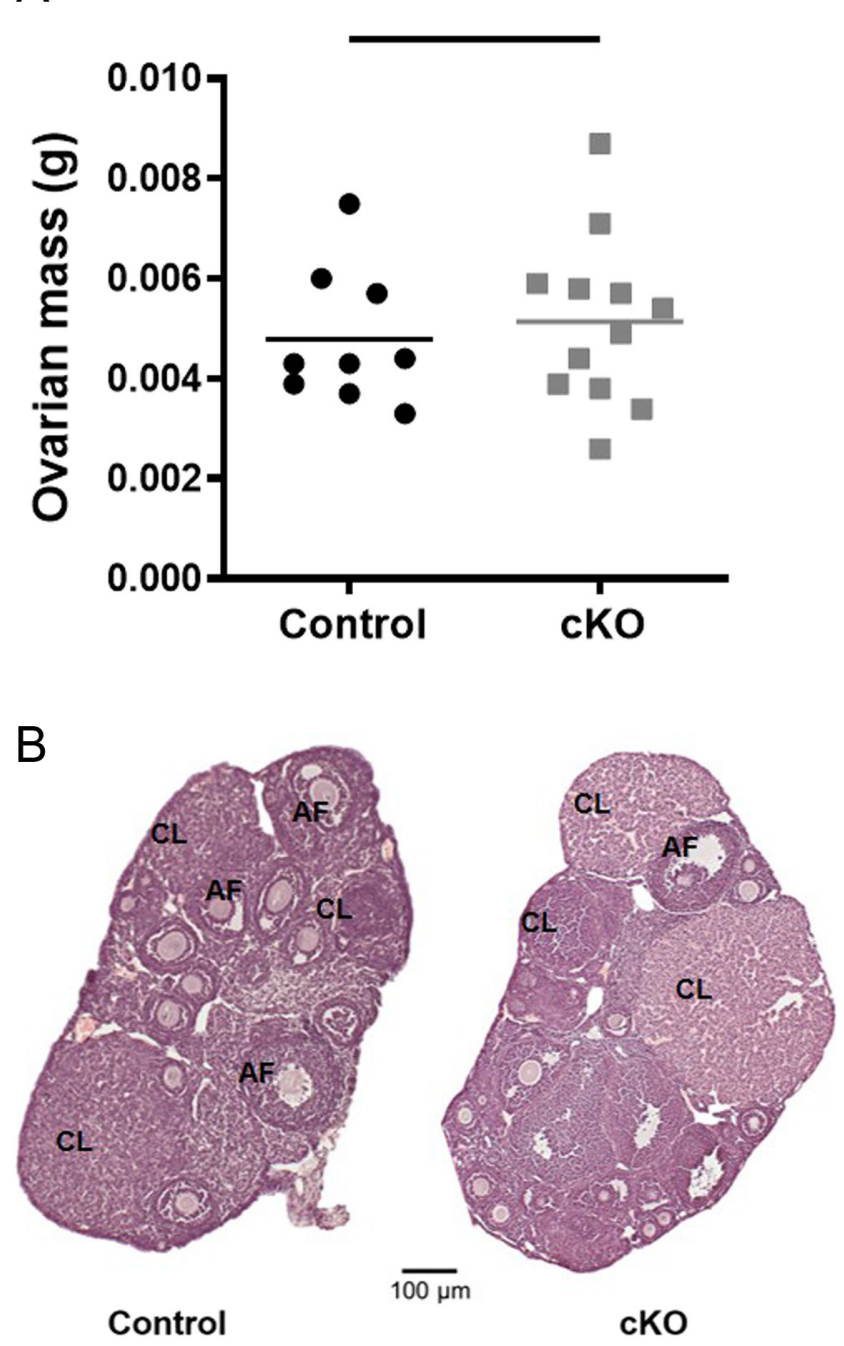

Figure 3 Normal ovarian weight and histology in cKO mice. (A) Ovarian weights were measured in 10-week-old female control $(n=9)$ and cKO $(n=12)$ mice. $t$-tests were used for statistical analyses. NS, not significantly different $(P>0.05)$. (B) H\&E-stained ovarian sections from representative 10-week-old control and cKO females.

\section{Discussion}

To assess potential roles of TGFBR3 in oocytes, we generated oocyte-specific Tgfbr3 knockout mice. The cKO females had normal ovarian histology and fecundity compared to littermate controls. The lack of a discernible phenotype is unlikely to be explained by incomplete Cre-mediated recombination, as cKO females passed the modified allele to all of their progeny. Rather, we suspect that, contrary to previous reports (Lewis et al. 2000, Drummond et al. 2002, Sarraj et al. 2007), it is absence of tangible Tgfbr3 expression in the murine oocyte that likely explains our results.

While several studies demonstrated strong immunostaining for TGFBR3 protein in both rat and murine oocytes (Lewis et al. 2000, Drummond et al.
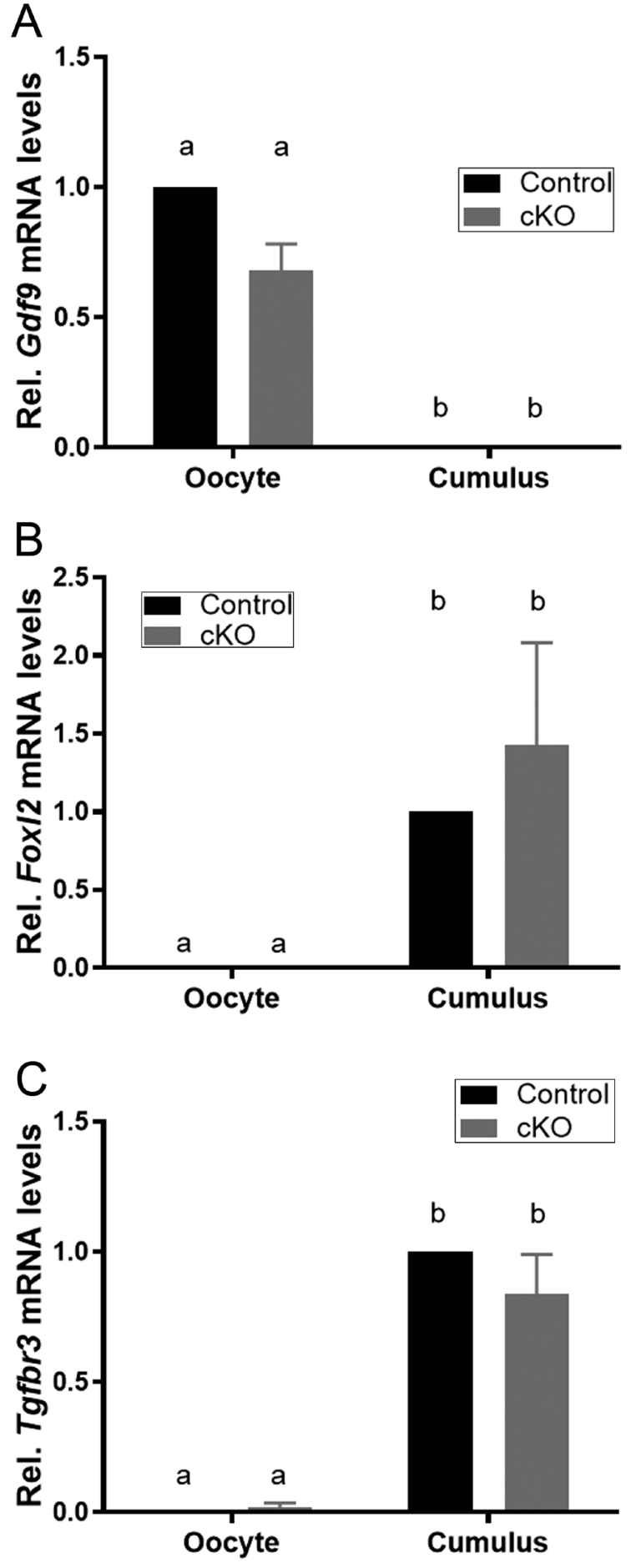

Figure $4 \mathrm{Tgfbr} 3$ is expressed in cumulus cells but not oocytes. Cumulus-oocyte complexes were collected from superovulated control $(n=3)$ and $\mathrm{CKO}(n=3)$ adult females. Complexes were dissociated and RNA was extracted separately from purified oocytes and cumulus cells. mRNA levels of Gdf9 (A), Fox/2 (B), and Tgfbr3 (C) were assessed by quantitative real-time PCR. In panel A, values for control oocytes were set to 1 . In panels $B$ and $C$, values for control cumulus cells were set to 1 . For all graphs, data are mean \pm S.E.M. Two-way ANOVAs were used for statistical analyses. Different letters indicate statistically significant differences $(P<0.05)$. 
2002, Sarraj et al. 2007), little to no expression of Tgfbr3 mRNA was observed in rat oocytes as assessed by in situ hybridization (MacConell et al. 2002). Our data from purified superovulated murine oocytes are consistent with this latter observation. We should note, however, that Tgfbr3 mRNA expression is down-regulated in cumulus cells after hCG treatment (Watson et al. 2012). Therefore, we cannot exclude the possibility that levels of Tgfbr 3 mRNA we observed in superovulated oocytes were lower than might be observed in vivo. Nevertheless, we had no difficulty in detecting Tgfbr3 mRNA in cumulus cells in the same experiment. As a result, we would argue that the discrepancies between the protein and mRNA data suggest that the immunostaining in previous publications was likely non-specific and that TGFBR3 protein is not actually expressed in murine oocytes. Indeed, we did not observe differences in TGFBR3 immunoreactivity in oocytes of control vs cKO mice, despite the completeness of the knockout (data not shown).

These results also comport with earlier observations that TGF $\beta$ family signaling may be more prominent in somatic cells than in oocytes. While TGF $\beta$ ligands, such as GDF9, are produced in the oocyte and signal in adjacent cumulus cells, it is possible that autocrine/ paracrine TGF $\beta$ signaling in oocytes is negligible (Dong et al. 1996, Knight \& Glister 2006). This idea is supported by the minimal fertility defects observed in oocyte-specific Smad4 knockout mice (Li et al. 2012). SMAD4, the Co-SMAD, mediates signaling by most TGF $\beta$ ligands. Whereas Smad4 deletion in oocytes is associated with only a small reduction in fertility, granulosa cell-specific Smad4 knockouts show impaired steroidogenesis, premature luteinization of granulosa cells, and premature ovarian failure (Pangas et al. 2006). These data suggest that TGF $\beta$ ligands may principally regulate fertility in female mice via their actions in granulosa cells rather than in oocytes.

In conclusion, Tgfbr3 mRNA expression is low in superovulated murine oocytes, likely explaining why the inactivation of the Tgfbr3 gene in these cells does not result in any fertility defects. In light of these data, we suggest that future studies of intraovarian functions of TGFBR3 focus on the protein's role in somatic cells.

\section{Declaration of interest}

The authors declare that there is no conflict of interest that could be perceived as prejudicing the impartiality of the research reported.

\section{Funding}

This work was supported by the Canadian Institutes of Health Research (operating grants MOP-89991 and PJT-162343 to D J B, and Canada Graduate Scholarship (Master's) to Y F L), a seed grant from the Réseau Québécois en reproduction (to D J B and $\mathrm{H}$ J C), a Dr Samuel Solomon Fellowship in Endocrinology from McGill University to $Y \mathrm{~L}$, and a James Frosst Award from McGill University to Y F L.

\section{Author contribution statement}

$Y L, H J C$, and D J B designed the experiments. $Y L$ and $X Z$ performed the experiments. $Y \mathrm{~L}$ and $\mathrm{D} J \mathrm{~B}$ analyzed the data. Y L, Y F L, and D J B wrote the manuscript, which was edited and approved by all co-authors.

\section{Acknowledgements}

The authors thank Qin Yang for providing technical assistance for oocyte and cumulus purification for this project, and Emilie Brûlé for providing feedback on an earlier version of the manuscript.

\section{References}

Attisano L \& Wrana JL 2002 Signal transduction by the TGF-beta superfamily. Science 296 1646-1647. (https://doi.org/10.1126/science.1071809)

Bilandzic M \& Stenvers KL 2011 Betaglycan: a multifunctional accessory. Molecular and Cellular Endocrinology 339 180-189. (https://doi. org/10.1016/j.mce.2011.04.014)

Caligioni CS 2009 Assessing reproductive status/stages in mice. Current Protocols in Neuroscience Appendix 4 Appendix 4l. (https://doi. org/10.1002/0471142301.nsa04is48)

Chapman SC, Bernard DJ, Jelen J \& Woodruff TK 2002 Properties of inhibin binding to betaglycan, InhBP/p120 and the activin type II receptors. Molecular and Cellular Endocrinology 196 79-93. (https://doi. org/10.1016/s0303-7207(02)00227-7)

Dong J, Albertini DF, Nishimori K, Kumar TR, Lu N \& Matzuk MM 1996 Growth differentiation factor-9 is required during early ovarian folliculogenesis. Nature 383 531-535. (https://doi. org/10.1038/383531a0)

Drummond AE, Le MT, Ethier JF, Dyson M \& Findlay JK 2002 Expression and localization of activin receptors, Smads, and beta glycan to the postnatal rat ovary. Endocrinology 143 1423-1433. (https://doi. org/10.1210/endo.143.4.8728)

Farnworth PG, Stanton PG, Wang Y, Escalona R, Findlay JK \& Ooi GT 2006 Inhibins differentially antagonize activin and bone morphogenetic protein action in a mouse adrenocortical cell line. Endocrinology 147 3462-3471. (https://doi.org/10.1210/en.2006-0023)

Gilchrist RB, Ritter LJ \& Armstrong DT 2004 Oocyte-somatic cell interactions during follicle development in mammals. Animal Reproduction Science 82-83 431-446. (https://doi.org/10.1016/j. anireprosci.2004.05.017)

Glister C, Satchell L \& Knight PG 2010 Changes in expression of bone morphogenetic proteins (BMPs), their receptors and inhibin co-receptor betaglycan during bovine antral follicle development: inhibin can antagonize the suppressive effect of BMPs on thecal androgen production. Reproduction 140 699-712. (https://doi.org/10.1530/REP-10-0216)

Hillier SG, Yong EL, Illingworth PJ, Baird DT, Schwall RH \& Mason AJ 1991 Effect of recombinant activin on androgen synthesis in cultured human thecal cells. Journal of Clinical Endocrinology and Metabolism 72 1206-1211. (https://doi.org/10.1210/jcem-72-6-1206)

Juengel JL \& McNatty KP 2005 The role of proteins of the transforming growth factor-beta superfamily in the intraovarian regulation of follicular development. Human Reproduction Update 11 143-160. (https://doi. org/10.1093/humupd/dmh061)

Kidder GM \& Vanderhyden BC 2010 Bidirectional communication between oocytes and follicle cells: ensuring oocyte developmental competence. Canadian Journal of Physiology and Pharmacology 88 399-413. (https:// doi.org/10.1139/y10-009) 
Knight PG \& Glister C 2006 TGF-beta superfamily members and ovarian follicle development. Reproduction 132 191-206. (https://doi. org/10.1530/rep.1.01074)

Knight PG, Satchell L \& Glister C 2012 Intra-ovarian roles of activins and inhibins. Molecular and Cellular Endocrinology 359 53-65. (https://doi. org/10.1016/j.mce.2011.04.024)

Lan ZJ, Xu X \& Cooney AJ 2004 Differential oocyte-specific expression of Cre recombinase activity in GDF-9-iCre, Zp3cre, and Msx2Cre transgenic mice. Biology of Reproduction 71 1469-1474. (https://doi. org/10.1095/biolreprod.104.031757)

Lewis KA, Gray PC, Blount AL, Macconell LA, Wiater E, Bilezikjian LM \& Vale W 2000 Betaglycan binds inhibin and can mediate functional antagonism of activin signalling. Nature 404 411-414. (https://doi. org/10.1038/35006129)

Li X, Tripurani SK, James R \& Pangas SA 2012 Minimal fertility defects in mice deficient in oocyte-expressed Smad4. Biology of Reproduction $\mathbf{8 6}$ 1-6. (https://doi.org/10.1095/biolreprod.111.094375)

Li Y, Schang G, Boehm U, Deng CX, Graff J \& Bernard DJ 2017 SMAD3 regulates follicle-stimulating hormone synthesis by pituitary gonadotrope cells in vivo. Journal of Biological Chemistry 292 2301-2314. (https:// doi.org/10.1074/jbc.M116.759167)

Li Y, Fortin J, Ongaro L, Zhou X, Boehm U, Schneyer A, Bernard DJ \& Lin HY 2018 Betaglycan (TGFBR3) functions as an inhibin A, but not inhibin B, coreceptor in pituitary gonadotrope cells in mice. Endocrinology 159 4077-4091. (https://doi.org/10.1210/en.2018-00770)

Ling N, Ying SY, Ueno N, Shimasaki S, Esch F, Hotta M \& Guillemin R 1986a A homodimer of the beta-subunits of inhibin A stimulates the secretion of pituitary follicle stimulating hormone. Biochemical and Biophysical Research Communications 138 1129-1137. (https://doi. org/10.1016/s0006-291x(86)80400-4)

Ling N, Ying SY, Ueno N, Shimasaki S, Esch F, Hotta M \& Guillemin R $1986 b$ Pituitary FSH is released by a heterodimer of the beta-subunits from the two forms of inhibin. Nature 321 779-782. (https://doi. org/10.1038/321779a0)

Macconell LA, Leal AM \& Vale WW 2002 The distribution of betaglycan protein and $\mathrm{mRNA}$ in rat brain, pituitary, and gonads: implications for a role for betaglycan in inhibin-mediated reproductive functions. Endocrinology 143 1066-1075. (https://doi.org/10.1210/endo.143.3.8707)

Massague J 1998 TGF-beta signal transduction. Annual Review of Biochemistry 67 753-791. (https://doi.org/10.1146/annurev. biochem.67.1.753)

Matzuk MM, Burns KH, Viveiros MM \& Eppig JJ 2002 Intercellular communication in the mammalian ovary: oocytes carry the conversation. Science 296 2178-2180. (https://doi.org/10.1126/science.1071965)

Myers M \& Pangas SA 2010 Regulatory roles of transforming growth factor beta family members in folliculogenesis. Wiley Interdisciplinary Reviews: Systems Biology and Medicine 2 117-125. (https://doi.org/10.1002/ wsbm.21)
O WS, Robertson DM \& de Kretser DM 1989 Inhibin as an oocyte meiotic inhibitor. Molecular and Cellular Endocrinology 62 307-311. (https:// doi.org/10.1016/0303-7207(89)90018-x)

Pangas SA, Li X, Robertson EJ \& Matzuk MM 2006 Premature luteinization and cumulus cell defects in ovarian-specific Smad4 knockout mice. Molecular Endocrinology 20 1406-1422. (https://doi.org/10.1210/ me.2005-0462)

Sadatsuki M, Tsutsumi O, Yamada R, Muramatsu M \& Taketani Y 1993 Local regulatory effects of activin $A$ and follistatin on meiotic maturation of rat oocytes. Biochemical and Biophysical Research Communications 196 388-395. (https://doi.org/10.1006/bbrc.1993.2261)

Sarraj MA, Chua HK, Umbers A, Loveland KL, Findlay JK \& Stenvers KL 2007 Differential expression of TGFBR3 (betaglycan) in mouse ovary and testis during gonadogenesis. Growth Factors 25 334-345. (https:// doi.org/10.1080/08977190701833619)

Silva CC \& Knight PG 1998 Modulatory actions of activin-A and follistatin on the developmental competence of in vitro-matured bovine oocytes. Biology of Reproduction 58 558-565. (https://doi.org/10.1095/ biolreprod58.2.558)

Silva CC, Groome NP \& Knight PG 1999 Demonstration of a suppressive effect of inhibin alpha-subunit on the developmental competence of in vitro matured bovine oocytes. Journal of Reproduction and Fertility 115 381-388. (https://doi.org/10.1530/jrf.0.1150381)

Vale W, Wiater E, Gray P, Harrison C, Bilezikjian L \& Choe S 2004 Activins and inhibins and their signaling. Annals of the New York Academy of Sciences 1038 142-147. (https://doi.org/10.1196/annals.1315.023)

Watson LN, Mottershead DG, Dunning KR, Robker RL, Gilchrist RB \& Russell DL 2012 Heparan sulfate proteoglycans regulate responses to oocyte paracrine signals in ovarian follicle morphogenesis. Endocrinology 153 4544-4555. (https://doi.org/10.1210/en.20121181)

Wiater E \& Vale W 2003 Inhibin is an antagonist of bone morphogenetic protein signaling. Journal of Biological Chemistry 278 7934-7941. (https://doi.org/10.1074/jbc.M209710200)

Wiater E, Lewis KA, Donaldson C, Vaughan J, Bilezikjian L \& Vale W 2009 Endogenous betaglycan is essential for high-potency inhibin antagonism in gonadotropes. Molecular Endocrinology 23 1033-1042. (https://doi. org/10.1210/me.2009-0021)

Received 13 September 2020

First decision 22 October 2020

Revised manuscript received 21 November 2020

Accepted 8 December 2020 